\title{
Komunitas Petani Kopi Ujung Bulu Jeneponto 1986-2018
}

\author{
Riskawati ${ }^{1}$, Ahmadin ${ }^{2}$, Bustan $^{3}$ \\ Pendidikan Sejarah Fakultas Ilmu Sosial Universitas Negeri Makassar \\ ${ }^{1}$ riskhawathy22@gmail.com, ${ }^{2}$ ahmadin@unm.ac.id, ${ }^{3}$ bustan@unm.ac.id
}

\begin{abstract}
Abstrak
Penelitian ini bertujuan untuk mendeskripsikan Petani Kopi di Desa Ujung Bulu 1986-2018 dengan memaparkan latar belakang petani kopi di Desa Ujung Bulu, dinamika pertanian kopi di Desa Ujung Bulu tahun 1986-2018, serta kehidupan sosial dan ekonomi Petani kopi di Desa Ujung Bulu. Hasil penelitian menunjukkan bahwa sebelum tahun 1986 sudah ada tanaman kopi yang tumbuh di Desa Ujung Bulu, masyarakat yang ada disana menyebutnya dengan Kopi Arabika Bantaeng. kopi yang kini dibudidayakan oleh masyarakat setempat adalah Kopi Arabika Gowa yang dibawa Oleh Bapak Lompo pada tahun 1986. Pembudidayaan kopi Arabika Gowa dimulai pada tahun 1989 dan pada tahun 1990an mulai banyak masyarakat setempat yang beralih profesi menjadi petani kopi. beralihnya masyarakat di Desa Ujung Bulu menjadi petani kopi disebabkan karena harga jual kopi lebih tinggi dibandingkan tanaman yang mereka tanam sebelumnya. Proses produksi dan pemasaran kopi arabika di Desa Ujung Bulu membutuhkan waktu yang lama dan proses yang tidak mudah. Produksi kopi di Desa Ujung Bulu tidak menetap atau mengalami peningkatan dan penurunan hasil produksi. Hal ini disebabkan oleh beberapa faktor, salah satunya adalah mulai masuknya bibir bawang merah di desa ini pada tahun 2015.Berdasarkan hasil penelitian, maka dapat disimpulkan bahwa pembudidayaan kopi Arabika di Desa Ujung Bulu memberikan dampak baik dalam bidang sosial maupun dalam bidang ekonomi terutama dalam mensejahterakan kehidupan masyarakat yang ada di Desa Ujung Bulu.Penelitian ini dilakukan melalui wawancara dan kajian pustaka dengan menggunakan metode penelitian sejarah dengan menempuh beberapa tahapan yaitu heuristik, kritik, interpretasi, dan historiografi. Wawancara dilakukan dengan aparat Desa Ujung Bulu dan beberapa Petani kopi di Desa Ujung Bulu.
\end{abstract}

Kata Kunci : Petani, Kopi dan Ujung Bulu

\begin{abstract}
This study aims to describe the Coffee Farmers in Ujung Bulu Village 1986-2018 by describing the background of coffee farmers in Ujung Bulu Village, the dynamics of coffee farming in Ujung Bulu Village in 1986-2018, and the social and economic life of coffee farmers in Ujung Bulu Village. The results showed that before 1986 there were coffee plants growing in Ujung Bulu Village, the people there called it Bantaeng Arabica Coffee. coffee which is now cultivated by the local community is Gowa Arabica Coffee which was brought by Mr. Lompo in 1986. The cultivation of Gowa Arabica coffee began in 1989 and in the 1990s many local people began to switch professions to become coffee farmers. the conversion of people in Ujung Bulu Village into coffee farmers was due to the higher selling price of coffee compared to the crops they had planted before. The process of producing and marketing Arabica coffee in Ujung Bulu Village takes a long time and is not an easy process. Coffee production in Ujung Bulu Village does not settle or has increased and decreased production yields. This is caused by several factors, one of which is the entry of onion lips in this village in 2015. Based on the results of the study, it can be concluded that the cultivation of Arabica coffee in Ujung Bulu Village has an impact both in the social and economic fields, especially in the welfare
\end{abstract}


community life in Ujung Bulu Village. This research was conducted through interviews and literature review using historical research methods by taking several stages, namely heuristics, criticism, interpretation, and historiography. Interviews were conducted with Ujung Bulu Village officials and several coffee farmers in Ujung Bulu Village.

Keywords: Farmer, Coffee and Ujung Bulu

\section{A. Pendahuluan}

Indonesia adalah salah satu negara berkembang yang memiliki lahan pertanian cukup luas. Jika diperhatikan dari barat sampai timur Indonesia, pertanian masih menjadi sumber mencari nafkah bagi sebagian besar penduduk Indonesia. Sebagai negara berkembang, persebaran pendapatan penduduknya tidak merata karena adanya ketimpangan sosial ekonomi yang dialami oleh penduduknya.

Kopi merupakan salah satu hasil komoditi perkebunan yang memiliki nilai ekonomis yang cukup tinggi di antara tanaman perkebunan lainnya. Kopi juga merupakan sumber penghasilan bagi petani Indonesia yang jumlahnya sekitar satu setengah juta jiwa. (Raharjo, 2012)

Kopi menjadi komoditi yang penting, karena di anggap minuman yang lezat rasanya. Dengan kata lain kopi adalah penyegar badan dan pikiran. Selain itu tanaman kopi juga mempunyai fungsi sosial dengan adanya perkebunan kopi yang besar, berarti pula memberi pekerjaan bagi orang-orang dan mengurangi jumlah pengangguran yang ada.

Dewasa ini, Kopi menjadi minuman yang digemari baik pria ataupun wanita serta berbagai golongan lainnya. Dahulu kopi dianggap sebagai minuman orang tua, tapi seiring berjalannya waktu kini kopi banyak digemari kalangan muda. Sebab kopi kini hadir dengan kemasan berbeda dan rasa bervariasi. Minuman penghilang rasa kantuk tersebut kini semakin digemari semua golongan masyarakat. sehingga semakin menjamurnya warung kopi (warkop) di beberapa tempat.

Menjamurnya warung kopi dibeberapa tempat dan meningkatnya permintaan kopi baik di dalam maupun luar daerah mendorong masyarakat untuk menanam tanaman kopi dan dan beralih profesi sebagai petani kopi. Seperti halnya di Desa Ujung Bulu, selain mengandalkan tanaman hortikultura seperti bawang merah, kol, wortel, tembakau dan sawi. Mayritas penduduk di Desa ujung bulu juga menanam tanaman kopi. dengan kata lain bahwa sebagian besar masyarakat yang ada di Desa Ujung Bulu berprofesi sebagai petani kopi.

Besarnya keuntungan yang diperoleh dari harga kopi yang terus meningkat membuat banyak negara berlomba-lomba untuk meraup keuntungan yang besar dengan membuka lahan-lahan perkebunan kopi. (Rahayu, 2015).

Salah satu kegiatan dalam penulisan karya ilmiah yang patut dilakukan adalah proses kegiatan tinjauan pustaka. Kajian pustaka merupakan telaah terhadap pustaka atau literatur yang menjadi landasan pemikiran dalam penelitian, dalam kaitanya dengan penelitian sejarah. Kajian pustaka penting untuk merekonstruksi suatu peristiwa yang memerlukaan rujukan agar karya tersebut dapat dipertanggungjawabkan. Kajian pustaka juga dapat menambah informasi yang dibutuhkan dalam proses penulisan.

Pada dasarnya penelitian mengenai petani kopi di suatu daerah telah banyak ditulis baik dalam bentuk buku, skripsi, jurnal. Seperti halnya buku yang ditulis oleh Pujdi Raharjo tahun 2012 mengenai "Panduan Budi Daya dan Pengelolahan Kopi Arabika dan Robusta " buku ini membahas tentang asal usulkopi, morfologi, pertumbuhan dan perkebangan kopi.

Selain buku yang ditulis oleh Pudji Raharjo ada pula buku yang ditulis oleh Yusnu Iman Nurhakim dan Sri Rahayu yang berjudul Perkebunan Kopi Skala Kecil 
Cepat Panen yang membahas tentang panduan dalam budidaya kopi secara intensif dan benar sehingga kopi dapat dipanen dengan cepat dengan kualitas terbaik. Selain itu buku ini juga membahas secara detail dan sistematis, mulai pemulihan tanaman kopi, persemaian, teknik bertanam, pemeliharaan, hama penyakit, pemanenan dan pasca panen, lengkap dengan alur niaga dan analisis usaha.

Adapun kajian relevan dari skripsi yang membahas tentang kopi dapat dilihat dari karya Nurhasma tahun 2015, jurusan pendidikan sejarah UNM, dengan judul Petani Kopi Arabika di Desa Labbo Kabupaten Bantaeng (1980-2016), yang membahas tentang latar belakang munculnya perkebunanan kopi Arabika di Desa Lappo Kabupaten Bantaeng pada tahun 1980, perkebunan kopi Arabika di Desa Lappo Kabupaten Bantaeng tahun 1980-2016, dan kehidupan sosial ekonomi petani kopi Arabika di Desa Lappo Kabupaten bantaeng. selain itu ada juga karya skripsi dari Fitriani tahun 2007, jurusan pendidikan sejarah UNM, dengan judul Petani Cengkeh di Manipi (19732008), yang membahas tentang latar belakang perkembangan cengkeh di Manipi, kehidupan sosial ekonomi petani cengkeh di Manipi, dan dampak sosial ekonomi perkembangan pertanian terhadap petani cengkeh di Manipi.

Kedua skripsi tersebut membahas tentang petani, begitu pun dengan penelitian ini, yang membedakan kedua skripsi tersebut dengan penelitian ini yaitu tempat penelitianya selain itu salah satu skripsi yang di jadikan kajian relevan membahas tentang petani cengkeh sedangkan penelitian ini membahas tentang petani kopi. selain perbedaan adapun beberapa kesamaan yang terdapat pada skripsi tersebut dan penelitian ini yaitu membahas tentang perkembangan petani dan kehidupan sosial ekonomi petani tersebut.Dan jurnal yang berjudul Perilaku Kewirausahaan Petani kopi Arabika Gayo di Kabupaten Bener Meriah Provinsi Aceh. (Zainura, 2012)

\section{B. Metode Penelitian}

Penelitian merupakan penelitian sejarah yang bersifat deskriptif analisis dengan tujuan untuk menemukan dan mendeskripsikan secara analitis serta menginterpretasi terkait perkembangan petani kopi di Desa Ujung Bulu kecamatan Rumbia kabupaten Jeneponto.

Berdasarkan uraian tersebut dapat disimpulkan bahwa metode sejarah merupakan cara atau teknik dalam merekonstruksi peristiwa masa lalu, melalui empat tahapan kerja yaitu heuristik (pengumplan data), Kritik Sumber (ekstern/bahan dan internal/isi), interpretasi (penafsiran) dan Historiografi (penulisan sejarah).

\section{Heuristik}

Pengumpulan sumber atau dalam kajian sejarah akan lebih dikenal dengan heuristic. Heuristik merupakan proses pencarian atau pengumpulan sumbersumber yang akan digunakan untuk merekonstruksi sejarah. Sebelum menentukan bentuk dari sumber sejarah yang akan di kumpulkan. Penentuan sember sejarah akan mempengaruhi tempat (dimana) atau siapa (sumber informasi lisan) dan cara memperolehnya. Sumber sejarah dibedakan atas sumber tulisan, lisan, dan benda. Sumber primer yang di tulis dalam sejarah umumnya berupa dokumen (arsip).

Dalam melakukan pengumpulan sumber, peneliti menempuh dua cara:

\section{a. Penelitian Pustaka}

Studi pustaka merupakan salah satu langkah penting dalam penelitian sejarah. Dalam studi pustaka ini akan di lakukan studi terhadap sejumlah bahas pustaka, baik yang berupa arsip, buku, dan hasil penelitian lainya yang memilikih kaitan topic penelitian ini. Bahan-bahan pustaka tersebut akan penulis peroleh dari perpustakaan sejarah FIS-UNM, Perpustakaan UNM, Perpustakaan 
Wilayah daerah Jeneponto dan Perpustakaan wilayah kota Makassar

\section{b. Penelitian Lapangan}

Kegiatan yang akan dilakukan dalam penelitian lapangan adalah mengadakan pengumpulan data secara langsung terhadap objek yang menjadi sasaran penelitian. Dalam hal ini penelitian menggunakan kegiatan observasi dan metode wawancara. Kegiatan tersebut dijelaskan sebagai berikut :

1) Observasi

Observasi adalah pengamatan secara langsung terhadap objek yang akan diteliti atau terhadap lokasi penelitian. Metode observasi yang peneliti maksud adalah mengadakan pengamatan dan penginderaan langsung terhadap masyarakat atau objek penelitian. Dalam hal ini peneliti telah melakukan observasi pada tempat penelitian. Peneliti Melakukan Observasi ada tanggal, 23 September 2018, 02 April 2019 dan 04 Mei 2019 di Desa Ujung Bulu Kecamatan Rumbia Kabupaten Jeneponto, pada observasi yang dilakukan, peneliti mendatangi Desa Ujung Bulu menggunakan Kendaraan pribadi dan melakukan wawancara dengan aparat desa setempat dan beberapa petani yang ada disana. Peneliti memiliki sedikit kendala karena bahasa yang digunakan oleh informan ada yang kurang dimengerti selain itu kendala lain yang dialami yaitu jarak antara rumah peneliti dan tempat yang akan di teliti lumayan jauh. Tapi kendala tersebut tidak mengalangi peneliti untuk melakukan penelitian.

\section{2) Wawancara}

Peneliti melakukan wawancara terhadap orang yang di anggap berkompoten dalam objek yang diteliti ini. Wawancara ini dilakukan dengan Kepala Desa Ujung Bulu, Sekertaris Desa, Beberapa Petani kopi di Desa Ujung Bulu, dan Bagian Pemasaran Kopi Bantolojong Turatea Cita Rasa Madu. Dalam hal ini di maksudkan agar para informan tidak merasa terpaksa memberikan keterangan yang di perlukan oleh peneliti. Hasil wawancara ini dapat di rekam dan di catat untuk selanjutnya di perbaiki pada saat penyusunan laporan penelitian. Selain itu, peneliti juga menggunakan dokumentasi penelitian. Hal tersebut di lakukan agar data yang diperoleh sifatnya objektif dan dapat dipertanggung jawabkan.

\section{Kritik Sumber}

Jika sumber-sumber yang digunakan dianggap cukup, langka selanjutnya adalah menilai sumber tersebut untuk menyeleksi dan menguji kebenaran dan keabsahan suatu sumber, guna mendapatkan data yang otentik. Dalam kritik sumber, terdapat penekanan tertentu yang bertujuan untuk memberikan definisi kritik sumber itu sendiri. Tujuan dari kegiatan-kegiatan ini adalah bahwa setelah sejarawan berhasil mengumpulkan sumber-sumber itu. Selanjutnya ia harus menyaringnya secara krits agar terjaring fakta yang menjadi pilihannya. Langkah-langkah inilah yang disebut kritik sumber, baik terhadaap bahan materi (ekstern) maupun terhadap subtansi (isi) sumber. (Sjamsuddin, 2012)

\section{Interpretasi}

Setelah tahap kritik sumber tahap selanjutnya ialah tahap interpretasi atau penafsiran. Fakta-fakta sejarah yang relavan sebagai hasil dari tahap sebelumnya mengalami proses penafsiran baik faktafakta yang beragam maupun yang berdiri sendiri untuk menjadi cerita yang utuh. Dalam tahap ini penulis dituntut untuk mampu menggunakan kemampuan imajinasi.

\section{Historiografi}

Tahap ini merupakan tahap berakhir dalam penelitian sejarah. Pada tahap ini peneliti akan menuliskan peristiwa sejarah tersebut dalam sebuah tulisan yang dalam penulisan, pemaparan dan pelaporan menggunakan tata cara tertentu. Dimana dalam hal ini, penelitian yang peneliti lakukan adalah penelitian dengan kajian kepustakaan dan lapangan.

\section{Pembahasan}

1. Latar belakang masyarakat desa ujung bulu menjadi petani kopi.

a. Masuknya Petani kopi Di Desa Ujung 


\section{Bulu.}

Budidaya kopi dikembangkan di Indonesia hampir tiga abad, yaitu sejak tanaman kopi untuk pertama kali dimasukkan ke Pulau Jawa di Zaman Hindia Belanda pada tahun 1696, bersamaan waktunya dengan digemarinya minuman kopi di Kawasan Eropa. Pertama kali dimasukkan bibit kopi Arabika asal dari Malabar-India dan di terima di Bogor untuk percobaan penanaman. (P.S.Siswoputranto, 1993)

Tanaman kopi bukan tanaman asli Indonesia, melainkan jenis tanaman yang berasal dari Benua Afrika. Sebelumnya telah di kemukakan bahwa kopi ini di bawa ke Pulau Jawa pada tahun 1696, tetapi pada waktu itu masih dalam taraf percobaan. (Aak, 1988)

Tanaman kopi telah di kenal oleh penduduk Sulawesi selatan sejak abad ke 17 dari pedagang Arab yang melakukan perdagangan dengan kerajaan Gowa. Dalam periode ini masyarakat Sulawesi Selatan mulai mengembangkan tanaman kopi di Gunung Lompobattang dan Toraja. Hal ini ini di perkirakan di prakarsai oleh raja Gowa dan pedagang Arab, Sehingga perkembanganya di Toraja berlangsung bersamaan dengan di Gowa (Gunung Lompobattang). Namun, komersiaalisasi komoditi kopi baru di lakukan pada tahun 1830 seiring dengan pengembangan tanaman kopi yang di lakukan oleh Pemerintah Hindia Belanda.

Di Sulawesi Selatan kopi dihasilkan terutama di Kabupaten Gowa, Banteng, Bulukumba, Sinjai, Enrekang, Tanah Toraja, Polamas dan Luwu. Terkenal daerah Tanah Toraja menghasilkan Kopi Arabika mutu tinggi, yang dikembangkan di tanah-tanah di atas 1.200 M. Indonesia belum memanfaatkan sungguh potensipotensi daerah Sulawesi Selatan untuk meningkatkan produksi Kopi Arabika. Padahal di Sulawesi Selatan memiliki daerah-daerah penghasil kopi yang bisa bersaing dengan daerah bahkan negara lain. (P.S.Siswoputranto, 1993)

Tanaman kopi jenis Arabika mulai dibudidayakan di Desa Ujung Bulu pada tahun 1986, yang dibawa oleh $\mathrm{H}$. Muhammad Lompo atau biasa dikenal Bapak Lompo. Beliau mengambil bibit kopi di daerah Gowa, sebenarnya sebelum tahun 1986 telah ada kopi yang tumbuh di daerah setempat yaitu kopi Arabika Bantaeng, tetapi kopi Arabika Bantaeng Memiliki Pohon yang tinggi sehingga agak menyulitkan petani jika ingin memanenya hal inilah yang membuat para petani tidak terlalu tertarik untuk menanam kopi pada waktu itu. Mereka lebih fokus menanam sayuran seperti kol, wortel dan kentang. Berbeda dengan kopi Arabika Bantaeng, Kopi Arabika yang dibawa oleh Bapak Lompo yang berasal dari Gowa nampaknya memiliki pohon yang lebih pendek dibandingkan kopi Arabika Bantaeng. sehingga kopi ini mulai ditanam dan dibudidayakan oleh Bapak Lompo sekitar tahun 1986. (Misi, 2019)

Kopi arabika yang kemudian ditanam oleh masyarakat setempat adalah anakan dari kopi yang telah dibudidayakan oleh Bapak Lompo. Ada juga beberapa petani yang mengambilnya langsung bibit Kopi Arabika di Daerah Gowa. (Mahamuddin, 2019)

Awalnya masyarakat setempat menanam tanaman kopi dilahan mereka yang masih kosong, atau mebagi 2 lahan yang ia punya. Misalkan, sang petani memiliki 4 hektar tanah maka 2 hektar tanah ia tanami sayuran dan 2 hektar lainya ia tanami kopi.ada juga beberapa petani yang memotong kopi yang mereka tanam dulu dan mengantinya dengan bibit kopi yang dibawa oleh Bapak Lompo. (Misi, 2019) Tanah untuk budidaya kopi perlu disiapkan dengan baik, perlu dibersihkan dari sisa-sisa tunggul pohon, agar tidak menjadi sumber penyakit akar maupun sumber gangguan nematode. (P.S.Siswoputranto, 1993)

\section{Perkembangan Awal Petani Kopi di Desa Ujung Bulu.}

Kopi menjadi bahan perdagangan, maka dalam mensukseskan perkebunana Kopi mendapat kepercayaan dan tugas 
berat dari pemerintah untuk menghasilkan bahan export. Sebab di negara-negara tertentu, terutama di Negara -negara Eropa, banyak orang yang suka minum Kopi, tetapi negaranya tidak menghasilkan, terpaksa harus membeli di Negara lain. (Aak, 1988)

Dengan hasil ekspor ini, Negara dapat memperoleh uang yang banyak, sehingga dapat dipergunakan untuk membeli alat-alat dan bahan-bahan industri yang di Negara kita yang belum ada. Tanaman kopi juga mempunyai fungsi sosial, sebab dengan adanya perkebunan Kopi yang besar itu, berarti peluang untuk memberikan pekerjaan bagi orang-orang yang berdekatan.

Sulawesi Selatan merupakan daerah agraris yang menjadi salah satu daerah lumbung pangan penghasil beras, kopi, jangung, cengkeh, rumput laut dan komoditas pertanian lainnya yang meningkatkan perekonomian Sulawesi Selatan. (Naim, 1999) Selain beras, Daerah Sulawesi Selatan juga dikenal sebagai daerah penghasil biji kopi yang berkualitas di Indonesia.Daerah penghasil kopi salah satunya adalah di Kabupaten Jeneponto tepatnya di Desa Ujung Bulu..

Pada tahun 1980an di Desa Ujung Bulu sudah ada tanaman kopi yang tumbuh. Masyarakat yang ada disana biasa meneyebutnya dengan kopi Arabika Bantaeng. tetapi kopi jenis Arabika Bantaeng belum banyak mendapat perhatian masyarakat yang ada disana karena batang kopi tersebut cukup tinggi sehingga sulit untuk dipetik buahnya. Sehingga masyarakat yang ada disana lebih memilih menanan sayuran seperti kol, wortel dan kentang serta jagung untuk di komsumsi pribadi.

Pada tahun 1986 Bapak Lompo mengambil beberapa bibit Kopi Arabika dari Gowa, kopi yang ada di daerah Gowa memiliki batang yang lebih pendek dari kopi yang telah dulu di tanam oleh masyakat setempat yaitu kopi Arabika Bantaeng. pada tahun 1986 belum banyak masyarakat yang menanam kopi, masyarakat yang ada disana sebagian besar menanam sayuran seperti kol, wortel dan kentang. Selain itu mereka juga menanam jagung untuk di komsumsi secara pribadi. (Misi, 2019)

Pada tahun 1989 kopi yang telah ditanam oleh Bapak Lompo sudah mulai berbuah dan ada beberapa pohon yang sudah bisa dipetik buahnya. Setelah dipetik dan dijual ternyata nilai jual kopi lebih tinggi dibandingkan dengan sayuran yang mereka tanam selama ini. Harga jual kopi perliternya berkisar Rp. 1000-2000 sedangkan harga jual wortel, kol, dan kentang hanya Rp. 250-500/kg. sehingga banyak petani yang ikut menanam kopi Arabika dan beralih profesi menjadi petani kopi seperti bapak Misi, Hamma, Abiding, Cama, Hasan dan beberapa orang lainya, mereka awalnya hanya menanam sayuran namun melihat harga jual kopi lebih tinggi dibandingkan harga jual sayuran yang mereka tanam maka mereka akhirnya lebih memilih menanam kopi. (Hading, 2019)

Sekitar tahun 1990an sebangian besar masyarakat di Desa Ujung Bulu mulai beralih profesi menjadi petani kopi. seperti yang dikemukan oleh Bapak Misi yang mengatakan bahwa "Sekitar tahun 1986 mulai banyak petani yang menanam tanaman kopi yang dibawa oleh Bapak Lompo". (Misi, 2019)Selain itu bapak Mahamuddin mengemukakan bahwa "Sekitar tahun 1990 para petani yang ada di Desa Ujung Bulu mulai mengambil bibit Kopi Arabika Gowa dan menanamnya di Desa Ujung Bulu”. (Mahamuddin, 2019). Mereka mulai membudidayakan tanaman kopi dilahan mereka yang masih kosong dan banyak diantara mereka yang memotong dan menganti kopi yang mereka tanam sebelumnya dengan kopi yang dibawa oleh Bapak Lompo.

Pada tahun 2000an produksi kopi di Desa Ujung Bulu semakin meningkat sehingga pada tahun 2009 mulailah di bentuk beberapa kelompok tani. Agar memudahkan masyakat dalam mengumpulkan hasil panennya. 
Pada tahun 2012 pemerintah setempat mulai melakukan hubungan kerjasama dengan dinas yang bersangkutan dengan pertanian, misalnya melakukan hubungan kerja sama dengan dinas pertanian baik dari kota Jeneponto sendiri maupun dengan dinas pertanian provinsi Sulawesi Selatan.

Pada tahun 2012 dilaksanakan penyuluhan yang di sebut SL-PHT atau Sekolah Lapang Pengendalian Hama Terpadu yang di selenggarakan oleh dinas pertanian Kota Makassar dimana Mereka di ajarkan cara meremajakan tanaman kopi dengan memotong batangnya dan memelihara tunasnya. Mereka juga di ajarkan cara memilah kopi, mana kopi yang baik dan yang tidak baik. Mereka juga diajarkan cara memetik kopi, dan memilah kopi. Hasil petikan kopi mempengaruhi harga jual kopi. Jika kopi yang dipetik secara langsung tanpa memilah maka harganya juga akan lebih rendah di bandingkan harga jual kopi yang di petik dengan cara memilah. Selain itu, mereka juga diajarkan bagaimana cara menanam kopi agar teratur dan mudah untuk di panen karena Sebelum adanya penyuluhan dari dinas pertanian para masyarakat menanam kopi secara tidak beraturan (Ardy., 2018).

Kegiatan panen kopi merupakan kegiatan akhir dari usaha budidaya tanaman kopi, sebelum kegiatan pengolahan buah kopi menjadi biji kopi kering. Panen buah kopi dalam suatu pohon perlu dilakukan dengan cermat agar hanya buah kopi yang masak/fisiologis yang dipanen, yaitu buah merah agar diperoleh mutu biji yang baik.

Cara pemetikan dan kecermatan pelaksanaan oleh tenaga-tenaga pemetik di kebun-kebun kopi merupakan awal yang amat menentukan mutu baik biji kopi. Perkebunan-perkebunan besar amat ketat mengawasi pelaksanaan pemetikan buah dan di beberapa Negara bahkan dilakukan keharusan menampi buah-buah yang dipetik untuk menghilangkan buah-buah kecil dan kotoran, ini semua dilakukan untuk menjamin diperolehnya biji-biji kopi yang benar-benar matang dan yang akan menghasilkan permintaan pasar yang kuat dengan harga-harga tinggi.

Pada tahun 2013 Bapak Mansyur (Kepala Desa Ujung Bulu) kemudian berinisiatif untuk mengelolah kopi yang ada di Desa Ujung Bulu menjadi sebuah produk dalam bentuk kemasan yang siap di pasarkan. Mengingat bahwa salah satu mata pendapatan terbesar di Desa Ujung Bulu adalah Kopi, hampir seluruh masyarakat disana memilki kopi. selain itu Bapak Mansyur juga ingin memperkenalkan Bahwa di Daerah Jeneponto khusunya di Desa Ujung Bulu juga memiliki kopi dengan kualitas yang cukup baik. Untuk merealisasikan ide tersebut kepala Desa Ujung Bulu yaitu Bapak Mansyur kemudian melakukan hubungan kerja samaa dengan para tokoh pemuda yang ada di sana.

Pada pertengahan tahun 2013 Bapak Mansyur kepala desa Ujung Bulu dan para tokoh pemuda yang ada di sana kemudian melakukan proses produksi kopi dan memberi nama produk tersebut dengan nama kopi cita rasa madu. Namun pada perkembangaanya kopi cita rasa madu ini kemudian di ganti menjadi Kopi Bontolojong Turatea cita rasa madu karena apabila brand yang di gunakan hanya kopi cita rasa madu itu terlalu sempit Karena dalam dunia kopi diketahui kalau madu itu honey proses jadi agak sempit karna hanya ada 1 proses kopi.

Pada perkembangan selanjutnya sekitar tahun 2013-2016 kemudian banyak sampel kopi yang di kirim ke Jakarta, Tagerang dan di daerah peneliti kopi untuk di lakukan riset untuk pengembangan mutu kopi. Kopi Bontolojong Turatea sendiri tetap menggunakan honey proses dimana prosesnya di halling dan di keringkan menggunakan lendir kopi, ada juga kopi yang pada proses pengelolahanya lendir dari kopi tersebut di cuci tetapi kopi bontolojong turatea cita rasa madu sendiri tidak menghilangkan lendirnya karena lender tersebutlah yang di sebut honey atau madunya. Jadi pada proses pembuatan kopi 
ini sama sekali tidak ada campuran madu atau ada lebah yang menghisapnya.

Pada tahun 2013 sebenarnya kopi Bontolojong Turatea Cita Rasa Madu telah diproduksi dan dipasarkan, tetapi masih sangat terbatas. Karena pada waktu itu pihak produsen masih melakukan riset agar mutu kopi yang ada di desa ini lebih baik lagi. Dan dapat bersaing dengan kopi-kopi yang ada baik di Sulawesi maupun di luar Sulawesi.

Telah banyak peneliti-peneliti kopi yang datang di desa ini baik dari dalam maupun luar negeri seperti dari Bekasi, Tangerang bahkan dari Filiphina, . Tujuan kedatangan mereka ke desa ini selain meneliiti, juga untuk menikmati secara langsung kopi bontolojong turatea cita rasa madu. Mereka penasaran dengan rasa kopi yang ada di desa ini yang katanya memiliki cita rasa tersendiri.

Dalam perkembanganya, produksi kopi Bontolojong turatea cita rasa madu terus dikembangkan, Pada tahun 2017, permintaan Produk kopi ini terus meningkat, bahkan hingga ke luar Sulawesi seperti Bekasi, Tangerang dan Malang. Namun dari pihak produsen dalam hal ini CV Bontolojong membatasi penjualan ke luar Sulawesi. Alasanya karena Produk kopi ini merupakan produk Lokal yang ingin diperkenalkan terlebih dahulu ke seluruh masyarakat Kabupaten Jeneponto, Selain itu terlalu banyak permintaan yang masuk dibandingkan ketersediahan bahan yang akan digunakan.

Kopi merupakan salah satu pendorong majunya Desa Ujung Bulu setelah berkembangnya perkebunan kopi Arabika sekitar tahun 1990an banyak masyarakat yang menjadikan pekerjaan sebagai petani kopi pekerjaan tetap ataupun pekerjaan sampingan. Pekerjaan bertani di Desa Ujung Bulu digeluti hampir seluruh kalangan mulai dari petani itu sendiri sampai kalangan pejabat pemerintahan. Sehingga tidak heran bila pertanian merupakan bagian dari kehidupan masyarakat perdesaan dalam meningkatkan produktivitas perekonomian (Mawaddah, 2018)

\section{Kesimpulan}

Berdasarkan uraian pembahasan yang telah dipaparkan pada halaman-halaman sebelumnya, maka kesimpulan yang dapat diangkat sebagai berikut.

1. Tanaman kopi jenis Arabika mulai dibudidayakan di Desa Ujung Bulu pada tahun 1986, yang dibawa oleh $\mathrm{H}$. Muhammad Lompo atau biasa dikenal Bapak Lompo. Beliau mengambil bibit kopi di daerah Gowa, sebenarnya sebelum tahun 1986 telah ada kopi yang tumbuh di daerah setempat yaitu kopi Arabika Bantaeng, tetapi kopi Arabika Bantaeng Memiliki Pohon yang tinggi sehingga agak menyulitkan petani jika ingin memanenya hal inilah yang membuat para petani tidak terlalu tertarik untuk menanam kopi pada waktu itu.

2. Masyarakat Desa Ujung Bulu Mulai Beralih Profesi menjadi petani kopi sekitar tahun 1990 hal ini disebabkan karena kopi yang telah dibudidayakan di Desa ini nampaknya memilikih nilai ekonomis yang lebih tinggi di bandingkan nilai jual sayuran yang erka tanam sebelumnya, selain masih banyaknya lahan mereka yang masih kopi sehingga lahan tersebut di tanami tanaman kopi.

\section{DAFTAR PUSTAKA}

AAK. 1998. Budidaya Kopi. Yogyakarta: Kanisius.

Ardy, 2019. Wawancara

[Interview] (Minggu, 23 September 2018).

Fitriani. 2011."Petani Cengkeh Di

Manipi Kabupaten Sinjai (1973-2007”).

Makassar: Skripsi Fakultas Ilmu Sosial

Universitas Negeri Makassar.

Hamid, A.R. dan Madjid. M.S,.

2011. Pengantar ilmu Sosial. Makassar. Ujung Pandang: Ombak. 
H. Hadding, 2019. Wawancara [Interview] ( Sabtu, 04 Mei 2019).

Kahfi, Asbabul.(2017) Budidaya dan produksi kopi di Sulawesi Selatan Abad ke- 19. Lensa Budaya : Journal of Cultural Sciences.12(1) ISSN: 0126 $351 X$

Misi, 2019. Wawancara [Interview] ( Selasa, 02 April 2019).

Mahamudddin, 2019. Wawancara [Interview] ( Sabtu, 04 Mei 2019).

Nurhakim, Y.I,. dan Sri rahayu. 2014. Perkebunan Kopi Skala Kecil Cepat Panen. Depok: Infra Pustaka.

Nurhamza. 2017. "Petani Kopi Arabika di Desa labbo Kabupaten Bantaeng 1980-2016". Skripsi. Fakultas Ilmu Sosial: Universitas Negeri Makassar.

Mawaddah. (2018) “ Petani Salak di Dusun Banca Kecamatan Barakka Kabupaten Enrekang 1960-2016. Jurnal Patinggaloang. 5(1)

P.S, Siswoputranto. 1993. Kopi Internasional Dan Indonesia. Yogyakarta: Kanisus.

Raharjo, Pudji. 2012. "KOPI: Panduan Budi Daya dan Pengelolahan Kopi Arabika dan Robusta".Jakarta: Penebar swadaya.

Rahardjo, Pudji.2017. Berkebun Kopi. Jakarta: Penebar Swadata,

Sjamsuddin, Helius. 2012. Metodologi Sejarah. Yogyakarta: Ombak. Zainura, Ulya, dkk. (2012) Perilaku Kewirausahaan Petani Kopi Arabika Gayo di Kabupaten Bener Meriah Provinsi Aceh. Jurnal Penyuluhan. 12(2). 